\title{
The Results of Arteriovenous Graft Placement in Hemodialysis Patients: Single Center Experience
}

\section{Hemodiyaliz Hastalarında Arteriyovenöz Greft Uygulama Sonuçları: Tek Merkez Deneyimi}

(i) İlhami Soykan BARLAS

Demiroğlu Bilim University Şişli Florence Nightingale Hospital, Department of General Surgery, İstanbul, Turkey

\begin{abstract}
Objective: Arteriovenous grafts (AVG) are the options of vascular access to be used in hemodialysis patients who do not have an arteriovenous fistula option in the upper extremity. In this study, we evaluated the graft survival and complication results of 39 patients who underwent AVG in our center.
\end{abstract}

Methods: Between 2010 and 2013, a total of 55 patients underwent AVG. As the records of 16 patients could not be reached, 39 patients were included in the study. The cases were retrospectively evaluated in terms of demographic data, AVG sites, survival with or without revision, factors affecting graft survival, and reasons for graft termination.

Results: The mean duration of graft use without revision was $9.9 \pm 8.5$ months and the mean total graft use was 13.6 \pm 11.6 months. The total graft survival rates were $82.1 \%, 74.1 \%$, and $35.3 \%$ at the end of the $2^{\text {nd }}, 12^{\text {th }}$, and $24^{\text {th }}$ months, respectively. The demographic data of the patients and the use of catheter or vascular access in the same side of the graft did not have a significant effect on graft survival or early complications. There was no significant difference in terms of survival time between the graft locations. The most common cause of AVG termination was thrombosis (43.6\%).

Conclusion: Although the rate of AVG which developed early functional loss was high in our study, first and second year survival rates in working grafts were similar with the literature. In conclusion, AVG is one of the important vascular access options with similar survival results with fistula in hemodialysispatients. Early graft loss can be reduced with preoperative venography.

Keywords: Arteriovenous graft, vascular access, hemodialysis

\section{ÖZ}

Amaç: Üst ekstremitede arteriovenöz fistül seçeneği bulunmayan hemodiyaliz hasta grubunda, uygulanması gereken damar yolu seçeneği arteriovenöz greftlerdir (AVG). Bu çalışmamızda, merkezimizde AVG uygulanmış 39 hastanın greft sağ kalım ve komplikasyon sonuçlarını değerlendirdik.

Yöntemler: 2010-2013 yılları arasında toplam 55 hastaya AVG uygulandı. On altı hastanın kayıtlarına ulaşılamadığı için 39 hasta çalışmaya alındı. Olgular; demografik veriler, AVG uygulanma bölgeleri, revizyonlu ve revizyonsuz sağ kalım süreleri, greft sağ kalımına etki eden faktörler ve greft sonlanma nedenleri açısından geriye dönük olarak değerlendirildi.

Bulgular: Revizyonsuz greft kullanım süresi ortalama $9,9 \pm 8,5$ ay, toplam greft kullanım süresi ortalama 13,6 $\pm 11,6$ aydı. İkinci ay sonunda toplam greft sağ kalımı \%82,1, 12. ayda \%74,1, 24. ayda $\% 35,3$ 'tü. Hastalara ait demografik verilerin, greft ile aynı taraf katater ya da damar yolu ameliyatı uygulanmış olmasının greft sağkalımına veya erken dönem komplikasyon gelişmesine anlamlı etkisi yoktu. Greft uygulanma bölgelerine göre sağ kalım süreleri açısından anlamlı fark saptanmadı. En sık AVG sonlanım nedeni tromboz gelişmesiydi $(\% 43,6)$.

Sonuç: Çalışmamızda erken dönemde fonksiyon kaybı gelişen AVG oranı yüksek olmasına rağmen, çalışan greftlerde birinci ve ikinci yıl sonu sağ kalım oranları literatürle benzer sonuçlara sahiptir. Sonuç olarak, AVG, fistüle yakın sağkalım sonuçlarıyla hemodiyaliz hastaları için önemli damaryolu seçeneklerinden biridir. Erken dönem greft kaybı ameliyat öncesi yapılacak olan venografi ile azaltılabilir.

Anahtar Sözcükler: Arteriovenöz greft, damar yolu, hemodiyaliz

Address for Correspondence: Ilthami Soykan BARLAS, Demiroğlu Bilim University Şişli Florence 


\section{Introduction}

In patients undergoing hemodialysis due to end stage renal disease, priority should always be given to autogenous arteriovenous fistulas (AVF) within the vascular access options (1). For some patients, on the other hand, AVF is not the most suitable vascular access option. In particular, 30-50\% of the forearm region fistulas are reported to have maturation problems that do not provide the blood flow required for hemodialysis $(2,3)$. Arteriovenous graft (AVG) can be used in patients in whom arteriovenous fistula option is not available or who do not have superficial vein (4), who are diabetic or elder and do not have vascular access, whose vascular access is damaged due to inappropriate and who is admitted for a new vascular access lately (5). A matured AVF has higher primary and secondary survival rates compared to graft $(6,7)$. However, low AVG survival in studies may be due to the fact that the patient group in whom AVG is placed is about 10 years older, have higher co-morbidities such as diabetes, cardiovascular disease and lupus, and has worse vascular anatomy (8). Also there are studies with large patient groups indicating that AVF and graft have equal survival outcomes (9). Therefore, the most important point to keep in mind is that in people who do not have the chance of AVF, the best option is graft, not catheter. The decision to create arteriovenous graft should be taken according to the detailed history of catheter and previous vascular access surgeries, a full physical examination and vascular mapping done by doppler ultrasound (10). Detailed vascular mapping, if possible, done by a vascular surgeon is the most important factor in finding autogenous vascular access options that have been overlooked and/or can be repaired and in reducing the number of unsuccessful surgical interventions.

\section{Methods}

Patients who underwent AVG in our clinic between January 2010 and June 2013 were retrospectively examined. Records for 16 of the total 55 patients could not be reached. Demographic data (age, gender and body mass index), area of the graft, survival times with and without revision, the patient's previous history of vascular surgery and catheter insertion from the same extremity, complications seen early after AVG administration and the reasons for the termination of the graft were recorded. The cumulative and individual effects of the the creation of graft in the forearm, upper arm or thigh on graft survival and effects of other data on graft survival were statistically analyzed. Grafts that stopped functioning in the first two months after surgery or that did not funciton at all were considered as primary failure.

\section{Surgical Technique}

The surgeries were performed with local anesthesia accompanied by sedation. A single dose of antibiotic prophylaxis was administered before the incision. Loop graft between brachial artery and antecubital vein in forearm (Figure 1), "C" graft between brachial artery in upper arm and basilic vein or parabracial vein in axilla (Figure 2), and loop graft between femoral artery and femoral vein in thigh region were preferred. The grafts that were thrombosed were evaluated with imaging methods and if appropriate underwent a surgical revision. After thrombectomy, the narrowed venous drainage end of the graft was repaired with patch angioplasty or a jump graft.

\section{Statistical Analysis}

The SPSS 15.0 for Windows package program was used for statistical analysis. Descriptive statistics were given as mean, standard deviation, minimum and maximum for numerical variables, and number and percentage for categorical variables. The comparison of the categorical variables between groups was tested by the chi-square test. The comparison of numerical variables between two independent groups was done with the Student t-test when there was normal distribution and with the Mann-Whitney U test when there was not normal distribution, and with the Kruskal-Wallis test in more than two groups. The relationship between numerical variables was examined with the Spearman correlation analysis because the conditions for parametric tests were not met. Graft survival rates were examined with the Kaplan-Meier analysis. Statistical alpha significance level was considered $\mathrm{p}<0.05$.

\section{Results}

Twenty of the patients were female $(51.3 \%)$, the average age was 58.6 \pm 11.7 years, and the average body mass index was $25.6 \pm 4.3$ $\mathrm{kg} / \mathrm{m}^{2}$. The demographic data of the patients, their AVG regions and their post-operative clinical results are shown in Table 1.

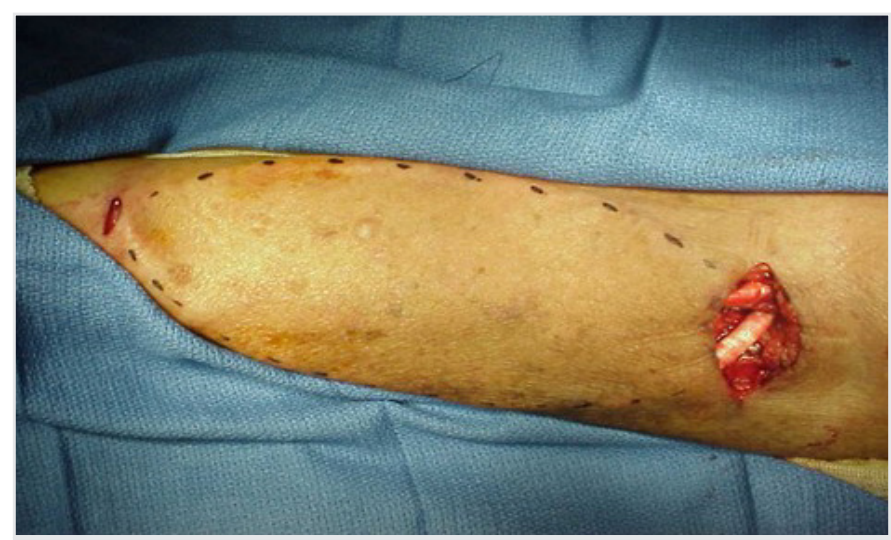

Figure 1. Forearm loop graft

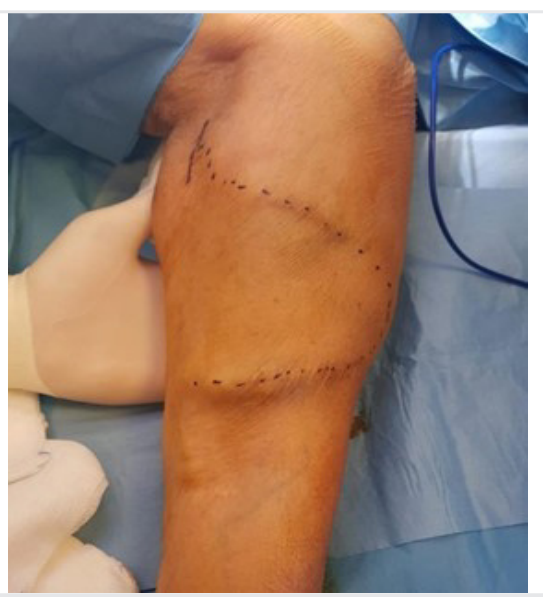

Figure 2. Upper arm C graft 
During the follow-up period, 21 patients had graft failure due to thrombosis, infection or arm edema. The two-month primary survival rate of patients with graft was $82 \%$, one-year $55.1 \%$, and two-year $26.4 \%$. Estimated median graft survival time was 17 months (95\% confidence interval=10.5-23.5 months) (Chart

Table 1. Demographic data, locations of AVG placement and postoperative clinical results of the patients

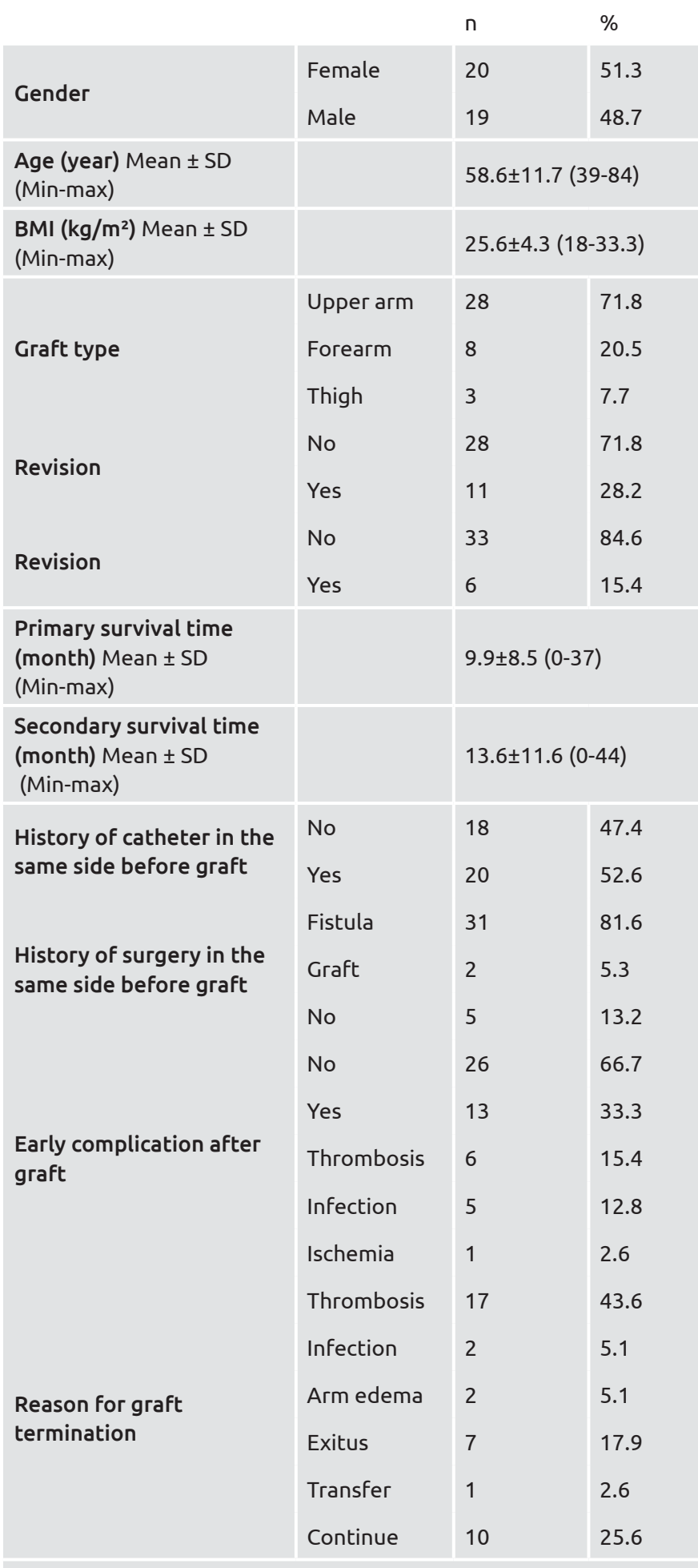

SD: Standart deviation, Min: Minimum, Max: Maximum, AVG: Arteriovenous grafts
1). With the revision, secondary one-and two-year graft survival rates increased to $74.1 \%$ and $35.3 \%$, respectively. There was no statistically significant difference between the groups when the survival rates of the AVGs were evaluated according to the areas where AVGs were placed $(\mathrm{p}=0,848)$ (Table 2, Chart 2). During the follow-up period, survival time was determined to be $9.9 \pm 8.5$ months when no revision was applied to AVG, and total graft survival time with revisions was $13.6 \pm 11.6$ months. Eleven $(28.2 \%)$ of the grafts that were terminated were found eligible for revision surgery after imaging was performed. Graft survival time was significantly higher in the patient group with revision than in the patient group without revision $(\mathrm{p}=0.001)$ (Table 3$)$.

In $33.3 \%$ of cases after the placement of AVG, complications such as thrombosis, ischemia or infection developed in the early period. However, there was no significant relationship between early complications and demographic data, catheter insertion to the same extremity, or history of previous vascular surgery (Table 4). In addition, there was no statistically significant difference in terms of AVG survival between patients with a history of catheter

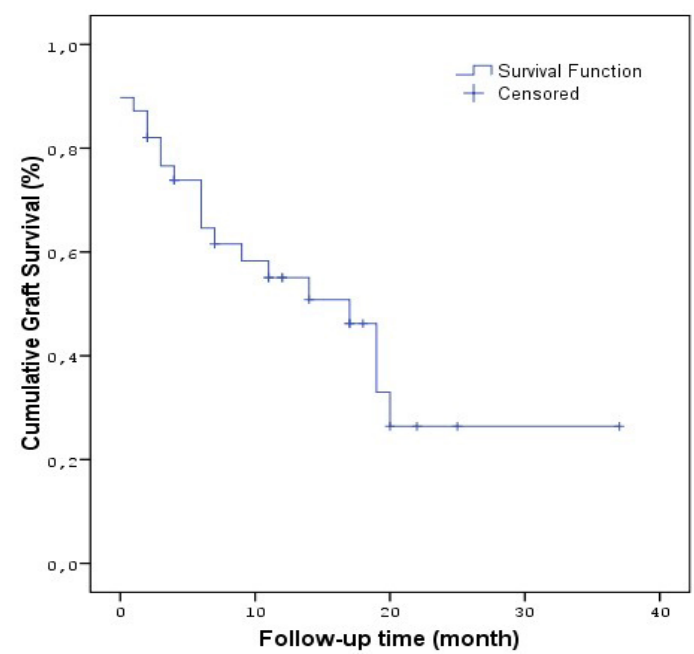

Chart 1. Assessment of cumulative AVG survival by KaplanMeier analysis

AVG: Arteriovenous grafts

Table 2. AVG survival results by placement locations

\begin{tabular}{|c|c|c|c|}
\hline & Upper arm & Forearm & Thigh \\
\hline $\begin{array}{l}\text { Estimated } \\
\text { median Life } \\
\text { Span }-95 \% \mathrm{Cl}\end{array}$ & $\begin{array}{l}17 \text { months (7.7- } \\
26.3 \text { months ) }\end{array}$ & 20 months (-) & 11 months (-) \\
\hline Time (month) & $\begin{array}{l}\text { Cumulative } \\
\text { graft survival } \\
\text { (\%) }\end{array}$ & $\begin{array}{l}\text { Cumulative } \\
\text { graft survival } \\
\text { (\%) }\end{array}$ & $\begin{array}{l}\text { Cumulative } \\
\text { graft survival } \\
\text { (\%) }\end{array}$ \\
\hline 2 months & $82.1 \%$ & $75.0 \%$ & $100 \%$ \\
\hline 12 months & $58.0 \%$ & $60.0 \%$ & $0.0 \%$ \\
\hline 24 months & $31.6 \%$ & - & - \\
\hline 36 months & $31.6 \%$ & - & \\
\hline
\end{tabular}


insertion and patients without a history of catheter insertion $(\mathrm{p}=0.848)$ (Chart 3).

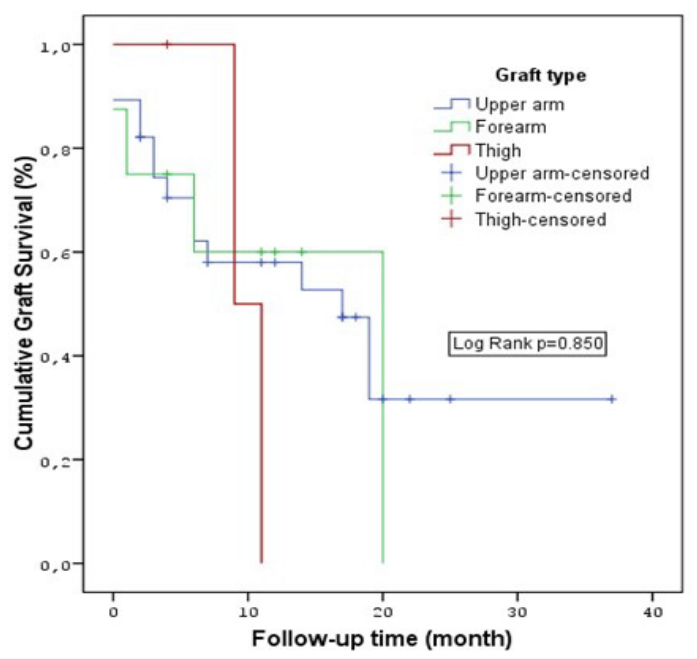

Chart 2. Evaluation of cumulative AVG survival by placement locations with Kaplan-Meier analysis

AVG: Arteriovenous grafts

Table 3. Primary and secondary cumulative AVG survival

\begin{tabular}{|c|c|c|}
\hline $\begin{array}{l}\text { Estimated median } \\
\text { graft life span }-95 \% \mathrm{Cl}\end{array}$ & $\begin{array}{l}17 \text { months ( } 95 \% \mathrm{Cl} \\
10.5-23.5 \text { months) }\end{array}$ & $\begin{array}{l}20 \text { months ( } 95 \% \mathrm{Cl} \\
13-27 \text { months) }\end{array}$ \\
\hline Time (month) & $\begin{array}{l}\text { Cumulative primary } \\
\text { graft survival (\%) }\end{array}$ & $\begin{array}{l}\text { Cumulative } \\
\text { secondary graft } \\
\text { survival (\%) }\end{array}$ \\
\hline 2 months & $82.1 \%$ & $82.1 \%$ \\
\hline 12 months & $55.1 \%$ & $74.1 \%$ \\
\hline 24 months & $26.4 \%$ & $35.3 \%$ \\
\hline 36 months & $26.4 \%$ & $28.2 \%$ \\
\hline
\end{tabular}

Cl: Confidence interval, AVG: Arteriovenous grafts

\section{Discussion}

Arteriovenous graft is often placed in the upper extremity and, more rarely, in the lower extremity. Although there are no differences in terms of primary and secondary patency times and complications between pre-arm and upper arm graft placement in upper extremity placements (11), it is recommended that priority be given to pre-arm graft placement in order to protect subsequent vascular access options (12). In our study, the ratio of upper arm graft placement was $71.8 \%$. The most important reason for this high ratio was that no available deep and superficial vascular access options were detected during the evaluation with doppler ultrasonography. In the lower extremity, AVG is usually placed in the thigh area. This is an important option for patients who do not have a chance of having a vascular access in

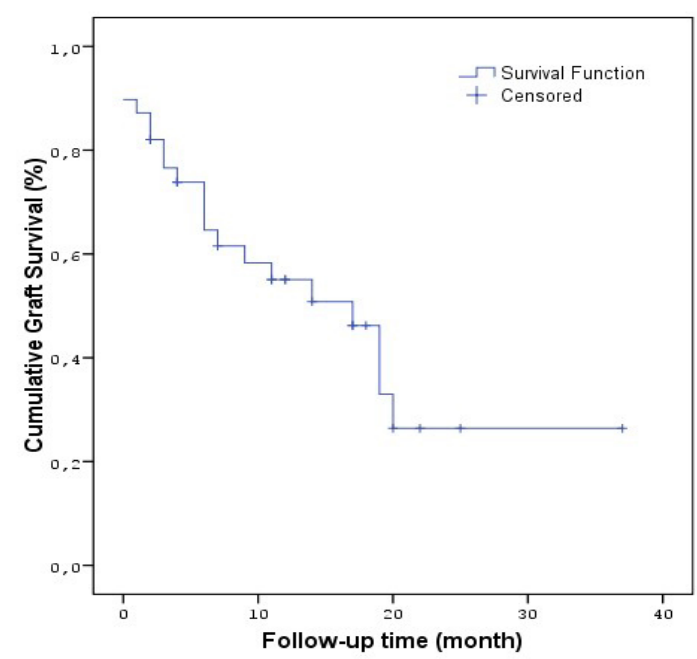

Chart 3. Evaluation of the effect of same-side extremity catheter placement on cumulative AVG survival by KaplanMeier analysis

AVG: Arteriovenous grafts

Table 4. Relationship between early complication and demography, catheter and previous vascular access surgery Early complication after graft

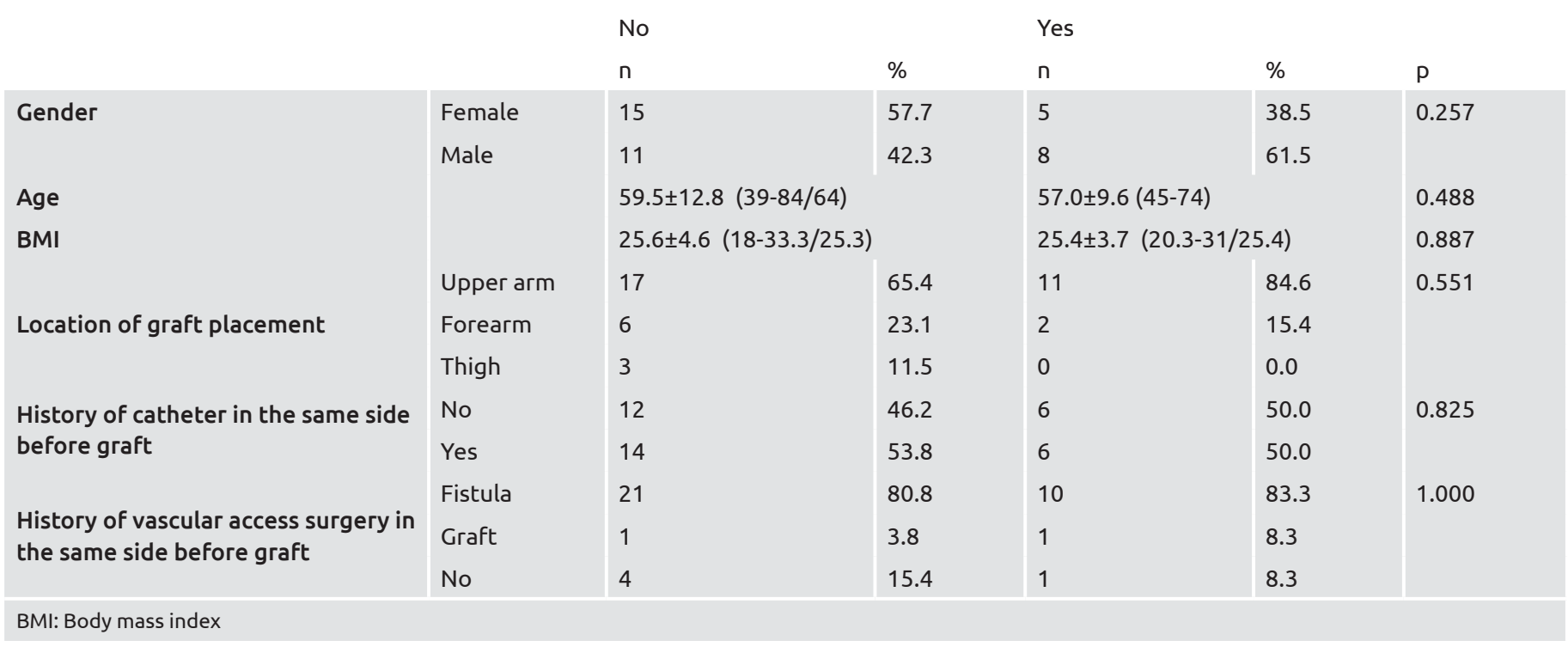


the upper extremity, even though it is not preferred due to the risk of infection. In our study, only $3(7.7 \%)$ patients had AVG placed in the thigh area. Studies have shown shorter primary and secondary patency times in AVGs placed in the thigh region $(13,14)$. Thigh grafts had shorter survival times in our study, although there was not a statistically significant difference in terms of graft survival times between placement areas of grafts.

The Kidney Disease Outcome Quality Initiative recommends that the rate of grafts that stop working within the first 30 days or the rate of grafts that never work should be less than $5 \%$ in the upper arm and $10 \%$ in the forearm (15). In two separate studies involving 289 and 128 patients with AVG, this ratio was given as $15 \%$ and $19 \%$, respectively $(16,17)$. This rate was $17.9 \%$ and $25 \%$ for the first two months in our study, respectively. This rate can often be associated with surgeryrelated technical problems, early cannulation-related hematoma or patient-related problems. In addition, we believe that one of the important factors to explain this high ratio is graft placement without imaging in order to prevent catheter use in patients who cannot undergo hemodialysis due to vascular access thrombosis. Akoh (10) showed in their systematic review that one-year and two-year cumulative AVG survival rates were $59-90 \%$ and 47 $85 \%$, respectively. In a different study, one-and two-year primary survival rates were reported as $74 \%$ and $50 \%$, and secondary survival rates were reported as $82 \%$ and $66 \%$ in patients who underwent AVG with systematic follow-up program (18). In our study, these rates were $55.1 \%$ and $26.4 \%$ for one-year primary and secondary survival, and $74.1 \%$ and $35.3 \%$ for two-year primary and secondary survival, respectively. We believe that the most important reason why our graft survival results were low was that the primary failure rate seen in the first two months was high.

Complications such as bleeding, thrombosis, and distal limb ischemia developed in one third of the cases in the early period after AVG placement. Shingarev et al. (19) examined the results of AVF and graft in patients having catheter placed in the same extremity in their study. They stated that catheter did not have an effect on primary failure in the early period, but that catheter might have a negative effect on long-term vascular access survival. Similarly, when the causes of these early complications were examined in our series, neither demographic data nor history of having catheter or AVF placed in the same extremity were found related with complications. However, in our study, when we evaluated the patients with and without catheter placed in the same extremity, no adverse effects of catheter were observed on long-term graft survival. At the end of the follow-up period, in 21 cases (53.8\%), AVG was terminated due to complications.

\section{Conclusion}

Arteriovenous graft placement is an important option that does not have maturation period, can easily be cannulated, has similar secondary survival time with AVF and allows long-term hemodialysis for patients with end-stage renal disease and it should be preferred before catheter. We believe that imaging of the central venous system before placement will reduce primary failure rates, but the results need to be supported by prospective studies with larger patient populations.

\section{Ethics}

Ethics Committee Approval: The article has an ethical committee.

Informed Consent: Most of the patients in the group were not alive due to their disease when the article was written. Therefore, it is not possible to receive informed consent from those patient later.

Peer-review: İnternally peer-reviewed.

Financial Disclosure: The authors declared that this study received no financial support.

\section{References}

1. NKF KDOQI Guidelines. Clinical Practice Guidelines and Clinical Practice Recommendations. 2006 Updates. Vascular Access. National Kidney Foundation Web site. http://www.kidney.org/professionals/ KDOQI/guideline_upHD_PD_VA/index.htm. Accessed June 23, 2009.

2. Berman SS, Mendoza B, Westerband A, Quick RC. Predicting arteriovenous fistula maturation with intraoperative blood flow measurements. J Vasc Access 2008;9:241-7.

3. Schild AF, Prieto J, Glenn M, Livingstone J, Alfieri K, Raines J. Maturation and failure rates in a large series of arteriovenous dialysis access fistulas. Vasc Endovascular Surg 2004;38:449-53.

4. Won T, Min SK, Jang JW, Choi SH, Choi KB, Han JJ, et al. Early result of arteriovenous graft with deep forearm veins as an outflow in hemodialysis patients. Ann Vasc Surg 2002;16:501-4.

5. Fan PY, Schwab SJ. Vascular access: concepts for the 1990s. J Am Soc Nephrol 1992;3:1-11.

6. Gibson KD, Caps MT, Kohler TR, Hatsukami TS, Gillen DL, Aldassy M, et al. Assessment of policy to reduce placement of prosthetic hemodialysis access. Kidney Int 2001;59:2335-45.

7. Mosquera D. Vascular access survival and incidence of revisions: a comparison of prosthetic grafts, simple autogenous fistulas, and venous transposition fistulas from the United States Renal Data System Dialysis Morbidity and Mortality Study. J Vasc Surg 2003;37:238-9.

8. Davidson I, Gallieni M, Saxena R, Dolmatch B. A patient centred decision making dialysis access algorythm. J Vasc Access 2007;8:5968.

9. Schild AF, Perez E, Gillaspie E, Seaver C, Livingstone J, Thibonnier A. Arteriovenous fistulae vs. arteriovenous grafts: A retrospective review of 1,700 consecutive vascular access cases. J Vasc Access 2008;9:231-5.

10. Akoh JA. Prosthetic arteriovenous grafts for hemodialysis. J Vascular Access 2009;10:137-47. 
11. Dixon BS, Beck GJ, Vazquez MA, Greenberg A, Delmez JA, Allon $\mathrm{M}$, et al. Effect of dipyridamole plus aspirin on hemodialysis graft patency. N Engl J Med 2009;360:2191-201.

12. Gage SM, Lawson JH. Forearm versus upper arm grafts for vascular access. J Vasc Access 2017;18:77-81.

13. Englesbe MJ, Al-Holou WN, Moyer AT, Robbins J, Pelletier SJ, Magee J, et al. Single centre review of femoral arteriovenous grafts for hemodialysis. World J Surg 2006;30:171-5.

14. Scott JD, Cull DL, Kalbaugh CA, Carsten CG, Blackhurst D, Taylor $\mathrm{SM}$, et al. The mid-thigh loop arteriovenous graft: patient selection, technique, and results. Am Surg 2006;72:825-8.

15. III. NKF-K/DOQI Clinical Practice Guidelines for Vascular Access: update 2000. Am J Kidney Dis 2001;37(suppl):S137-81.
16. Maya ID, O’Neal JC, Young CJ, Barker-Finkel J, Allon M. Outcomes of brachiocephalic fistulas, transposed brachiobasilic fistulas, and upper arm grafts. Clin J Am Soc Nephrol 2009;4:86-92.

17. Lok CE, Sontrop JM, Tomlinson G, RajanD, Cattral M, Oreopoulos $\mathrm{G}$, et al. Cumulative patency of contemporary fistulas versus grafts (2000-2010). Clin J Am Soc Nephrol 2013;8:810-8.

18. Caro AP, Marchante R, Thuissard IJ, Sanz-Rosa D, Amann R, Hernandez B, et al. A systematic follow-up protocol achieving a low hemodialysis graft thrombosis rate. J Vasc Access 2019:1129729819838795.

19. Shingarev R, Barker-Finkel J, Allon M. Association of hemodialysis central venous catheter use with ipsilateral arteriovenous vascular access survival. Am J Kidney Dis 2012;60:983-9. 